\title{
FSSIM, a bio-economic farm model for simulating the response of EU farming systems to agricultural and environmental policies
}

\author{
Kamel Louhichi , Argyris Kanellopoulos , Sander Janssen , Guillermo Flichman , Maria Blanco , \\ Huib Hengsdijk , Thomas Heckelei , Paul Berentsen , Alfons Oude Lansink , Martin Van Ittersum \\ INRA-UMR Economie Publique, Aventue Lucien Brétiguières, 78850 Thiverval-Grignon, France \\ Business Economics, Wageningen University. Hollandseweg 1, $6706 \mathrm{KN}$ Wogeningen. The Netherlands \\ Plant Production Systems, Wogeningen University, P.O. BoX 430, 6700 AK Wageningen. The Netherlands \\ IAMM-CIHEAM, 3191 Route de Mende, 34093 Cedex 5. Montpellier, France \\ European Commission joint Research Centre (IRC), iPTS, Edificio Expo, Inca Garcilaso 3, 41092 Sevilla. Spain \\ Plant Research international, Wageningen University, P.O. Box 616, 6700 AK Wageningen, The Netheriands \\ University of Bonn, Econonic and Agricaltural Policy, Nussallee 21, 53115 Bonn, Germany
}

Keywords:

Bio-economic model

Integrated assessment

Environmental policy

Market liberalization

\begin{abstract}
A B S T R A C T
The disciplinary nature of most existing farm models as well as the issue specific orientation of most of the studies in agricultural systems research are main reasons for the limited use and re-use of bio-economic modelling for the ex-ante integrated assessment of policy decisions. The objective of this article is to present a bio-economic farm model that is generic and re-usable for different bio-physical and socio-economic contexts, facilitating the linking of micro and macro analysis or to provide detailed analysis of farming systems in a specific region. Model use is illustrated in this paper with an analysis of the impacts of the CAP reform of 2003 for arable and livestock farms in a context of market liberalization. Results from the application of the model to representative farms in Flevoland (the Netherlands) and Midi-Pyrenees (France) shows that CAP reform 2003 under market liberalization will cause substantial substitution of root crops and durum wheat by vegetables and oilseed crops. Much of the set-aside area will be put into production intensifying the existing farming systems. Abolishment of the milk quota system will cause an increase of the average herd size. The average total gross margin of farm types in Flevoland decreases while the average total gross margin of farms in Midi-Pyrenees increases. The results show that the model can simulate arable and livestock farm types of two regions different from a biophysical and socio-economic point of view and it can deal with a variety of policy instruments. The examples show that the model can be (re-)used as a basis for future research and as a comprehensive tool for future policy analysis.
\end{abstract}

\section{Introduction}

Governments and policy agencies attempt to assess consequences of new policies before their introduction. The European Commission has formalized this through a mandatory ex-ante impact assessment of its new agricultural and environmental policies (EC, 2005). Science can contribute to these governmental demands for impact assessment by developing tools that can, in a transparent, rigorous and repeatable fashion, make impact assessments of agricultural and environmental policies better informed. Bioeconomic farm models have been proposed for such ex-ante assessments (Flichman and Jacquet, 2003; Janssen and Van Jttersum, 2007) and many recent applications (Donaldson et al., 1995; Flichman, 1996; Judez et al., 2001;Berentsen, 2003; Veysset et al., 2005; Onate et al., 2006; Riesgo and Gomez-Limon, 2006; Semaan et al., 2007) assess the impacts of policy changes on economic, environmental and social indicators of agricultural systems. If a bio-economic farm model is to be used as a basis for such exante assessments of agricultural and environmental policies at European level, some requirements must be fulfilled, i.e. it must be possible to upscale the model's results (e.g. product supply) to higher system levels (e.g. country or market); data with respect to farm types, their locations and production activities must be readily available throughout various regions; the model must be applicable to different farm types including mixed farm types; the application and calibration of the model should not require many ad hoc steps or unjustified strict calibration constraints, and finally it must be possible to assess many different policy 
instruments. In short, it must be possible to use and apply the same bio-economic farm model in a consistent way across the European Union (EU).

A literature review showed that a generic model meeting the above requirements does not exist (Janssen and Van Ittersum, 2007). Some models focus on simulating specific farm types without providing much opportunities to expand their application beyond the original target domain (e.g. Donaldson et al., 1995; Veysset et al., 2005), while other models require extensive data collection limiting a rapid operationalization (e.g. Riesgo and Gomez-Limon, 2006). Various model applications address very specific EU policy issues and do not allow the assessment of a range of interrelated policy questions that EU decision-makers face (Topp and Mitchell, 2003; Onate et al., 2006).

Each of these models (Donaldson et al., 1995; Topp and Mitchell, 2003; Veysset et al., 2005: Riesgo and Gomez-Limon, 2006) has strengths that made them suitable to be used for specific data-sets and applications. In trying to extend their use to other policies questions and locations, this specificity causes problems. With the limitations of existing approaches in mind, this article has the following two objectives. The first objective is to present the Farm System SIMulator (FSSIM) which aims to be a generic bioeconomic farm model that can be applied in combination with higher level models to assess, ex-ante, a variety of policy questions under different bio-physical and socio-economic conditions. The second objective is to demonstrate the applicability of the mode] as a stand alone tool to assess farm level impact of future policy scenarios for different farm types in different regions. FSSIM has been developed as part of the integrated modelling framework of the System for Environmental and Agricultural Modelling: Linking European Science and Society (SEAMLESS) (Van Ittersum et al., 2008) which targets to integrated assessment of agricultural systems in the EU of 27 member states (EU27). This implies that FSSIM can be and has been linked to other models for multi-scale analyses (Pérez Dominguez et al., 2009).

In Section 2, the SEAMLESS context and the requirements for a model like FSSIM are presented to justify the modelling choices. In Section 3, FSSIM is described. In Section 4, the model is used to simulate arable and dairy farms of Flevoland (The Netherlands) and Midi-Pyrenees (France). In Section 5, the results of the application of FSSIM are described. Section 6 discusses the results and concludes.

\section{Model requirements following from the SEAMLESS Integrated Framework}

The main objective of the SEAMLESS Integrated Framework (SEAMLESS-IF) is to enable ex-ante evaluation of a broad range of agricultural and environmental policies at multiple decision making levels. This framework consists of models which operate in an iterative way (Fig. 1). First, the Common Agricultural Policy Regionalized Impact modelling system (CAPRI) which is an EU agricultural sector model (Britz et al., 2007) is used to estimate a set of initial prices for the agricultural products of all EU27 regions. Second, FSSIM uses the estimated prices and calculates supply re-

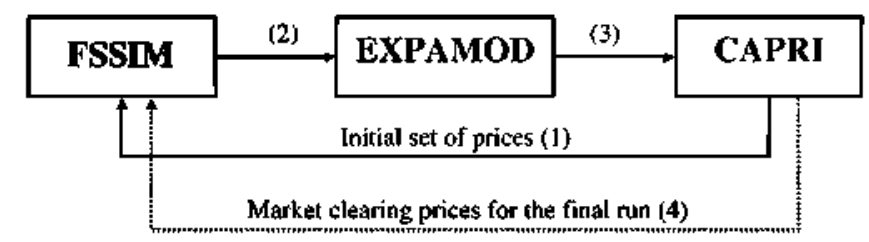

Fig. 1. SEAMLESS model chain (Pérez Domínguez et al., 2009). See text for explanation. sponses of farms to price shocks in a selection of EU 27 regions. Third. EXPAMOD (Pérez Dominguez et al., 2009) is used to extrapolate results of the sample regions to all EU27 regions by means of econometric approaches. Next, CAPRI is recalibrated with the new supply responses coming from EXPAMOD to generate a set of market clearing prices that are used by FSSIM for the final run.

Modelling all individual farms within EU27 is not possible because of the large number of farms and the existing variation and diversification among farming systems. Therefore, a farm typology was developed associating economic and environmental characteristics of EU farms. This farm typology is based on the existing EU farm typology (EEC, 1985) which classifies farms according to their income and specialization. This farm typology has been enriched with environmental criteria related to the land use and intensity of farming (Andersen et al., 2007).

A spatial allocation procedure was developed to geo-reference farm types allowing the aggregation of model results at farm type level to both natural (territorial) and administrative regional level (Elbersen et al., 2006; Hazeu et al., 2010). FSSIM is used to simulate an "average farm" which is a virtual (not observed in reality) farm derived by averaging data from the Farm Accountancy Data Network (FADN) of farms that are grouped in the same farm type. It is assumed that the "average farm" represents all farms that belong to the same farm type. Structural changes in the sector are related to interactions between farms (land market) and alternative income sources and can only be taken into account by using another model (Zimmermann et al., 2009) of SEAMLESS-JF. However, policy makers can compare the gross margin of an average farm calculated by FSSIM with the estimated income from non-farming activities to draw conclusions on the viability of the particular average farm.

The general context of SEAMLESS and the variety of policy questions that FSSIM should be able to address leads to a number of model requirements. First, FSSIM must be integrated with the other models of SEAMLESS-JF. The integration with components at field and market level must be streamlined in terms of methodology (e.g. temporal and spatial scales), concepts and scenarios being used and software. Second, the conceptual design of FSSIM should be "generic" so that the model can be easily modified and used for assessing different policies under various socio-economic and bio-physical conditions (e.g. different farm types and different regions). Third, production activities and available technology must be described in an explicit and transparent way to improve the explanatory power of the model. Fourth, the data needs of FSSIM should be preferably limited to those data available at EU27 level minimizing the resource demanding process of data collection. The model must be robust enough to function with data like those from FADN. Moreover, the model should be capable to exploit more detailed data that is not currently available but might become available in the future. Finally, FSSIM should be easily adaptable and re-usable (modularity). This will allow model users to easily change it to account for different regions, farming systems, and policies.

\section{Model description}

\subsection{Model specification}

FSSIM is an optimization model which maximizes a farm's total gross margin subject to a set of resource and policy constraints. Total gross margin is defined as total revenues including sales from agricultural products and compensatory payments (subsidies) minus total variable costs from crop and animal production. Total variable costs include costs of fertilizers, costs of irrigation water, costs of crop protection, costs of seeds and plant material, costs of animal feed and costs of hired labour. A quadratic objective 
function is used to account for increasing variable costs per unit of production because of inadequate machinery and management capacity and decreasing yields due to land heterogeneity (Howitt, 1995). The general mathematical formulation of FSSIM is presented below:

maximize $Z=\mathbf{w}^{\prime} \mathbf{x}-\mathbf{x}^{\prime} \mathbf{Q} \mathbf{x}$

subject to $A \mathbf{x} \leqslant \mathbf{b}, \quad \mathbf{x} \geqslant 0$

where $Z$ is the total gross margin, $w$ is the $n \times 1$ vector of the parameters of the linear part of the activities' gross margin, $Q$ is the $n \times n$ matrix of the parameters of the quadratic part of the activities' gross margin, $\mathbf{x}$ is a $n \times 1$ vector of the simulated levels of the agricultural activities, $\mathbf{A}$ is a $\boldsymbol{m} \times \boldsymbol{n}$ matrix of technical coefficients, and $\mathbf{b}$ is a $m \times 1$ vector of available resources and upper bounds to the policy constraints.

A different model formulation has already been implemented and can be used if detailed agro-management information is available or if it is important to account for the risk averse attitude of the farmer explicitly. In this model formulation the farmer's utility is maximized. Utility is defined as gross margin minus risk. For this specification a linear gross margin function is assumed.

maximize $U=\mathbf{w}^{\prime} \mathbf{x}-\varphi \sigma$

subject to $\mathbf{A x} \leqslant \mathbf{b}, \quad \mathbf{x} \geqslant 0$

where $\varphi$ is the risk aversion parameter that assumes constant absolute risk aversion (Hazell and Notton, 1986) and $\sigma$ is the standard deviation of the total gross margin.

FSSIM consists of four major components, i.e. arable production, livestock production, policies and regulations and the calibration and forecasting component which are described below.

\subsubsection{Arable production}

In FSSIM, arable agricultural activities are defined as crop rotations grown under specific soil and climate conditions and under well-defined management describing major field operations in detail. It is assumed that in each year, all crops of a rotation are grown on equal shares of the land. A model solution can include several crop rotations. The concept of crop rotations allows to account for temporal interactions between crops. The agricultural management of arable activities describes operations associated with fertilization, soil preparation, sowing, harvesting, irrigation and pest management of crops and results in different inputs and outputs.

FSSIM uses information available in FADN. This data source lacks detail in agro-management information which is needed to assess the environmental aspects of production. Therefore, a simple survey was performed within SEAMLESS to identify and quantify current production activities (Borkowski et al., 2007; Zander et al., 2010). For operational purposes and due to resource limitations the survey was conducted for a sample of 16 NUTS2 regions from the EU27 (NUTS: Nomenclature of Territorial Units for Statistics). Experts from the sampled regions were asked to specify the most important rotations and related management which are currently used by arable farms in their region. In total 87 rotations of 21 different crops were identified in the sampled regions.

The agricultural management component of FSSIM (FSSIM-AM) and the Agricultural Production Externalities Simulator (APES) (Janssen et al., 2009b) can be used to quantify externalities of current activities (e.g. N-leaching) and complete sets of discrete input and outputs coefficients (e.g. costs, labour requirements, input of agrochemicals, yields, externalities) for alternative activities which have improved performance in one or more criteria. Alternative arable activities may include new crops and rotations, changes in crop management or their combination resulting in activities with different technical coefficients. Alternative activities are used to account for technological innovations in agriculture (e.g. new varie- ties, modern agricultural practices) and effects of future changes to bio-physical and climatic conditions (e.g. effects of climate change or soil degradation to production).

Arable farmers face a number of resource scarcities that affect their decision making. These resource scarcities have been taken into account in FSSIM by means of constraints. The available arable land constraint is specified per soil type and ensures that the sum of the area of the activities on a certain soil does not exceed the available farm land for this soil type. The available land is derived from FADN and hence imposed exogenously. Selling or buying of land is not considered in FSSIM. However, pre-determined scenarjos with more (in case of buying) or less (in case of selling) available land can be tested. The available itrigated land constraint ensures that the area with irrigated activities does not exceed the available irrigable land. The available amount of irrigation water constraint ensures that the total volume of water required for the irrigated activities does not exceed the available water volume. Finally, the labour constraint is used to calculate the number of hours of hired labour, given the labour requirements of different activities and the availability of family labour. Hired labour is considered as an additional cost, the price of which is equal to the average region-specific wage rate. Allocation of family labour to off-farm activities is not considered in FSSIM. Scenarios can be used to assess consequences of allocating family labour to off-farm activities by changing the availability of family labour for agricultural activities.

\subsubsection{Livestock production}

Three different animal activities are modelled in FSSIM, i.e. dairy, beef, and small ruminants (sheep and goats). The core element of a dairy activity is a productive cow, a bull and their off-springs. A replacement rate is based on the actual milk production per cow and sets the share of young animals in a dairy activity i.e. calves and heifers. For example, a typical dairy activity in Flevoland may consist of $60.5 \%$ cows, $17.5 \%$ heifers, $20.8 \%$ calves and $1.2 \%$ bulls. Increasing the activity level by 1 unit will cause an increase in the number of all animals so that the share of animals in the activity remains constant. Feed requirements of different animal types and decisions on the length of the grazing period are also taken into account in a dairy activity. The feed requirements of the herd in terms of fibre, energy and protein are covered by roughage produced onfarm (fresh, hay or silage), purchased roughage (hay or silage), concentrates produced on-farm or purchased concentrates. Feed crops like grass and fodder maize are grown either in a rotation with other crops or as mono-crop activities. The quantities of on-farm produced and purchased feed depend mainly on prices of crop product (including feed) and input prices. Beef activities are modelled in a similar way. Two distinct methods of raising animals for beef production are available i.e. a suckler system comprising a cow and its offsprings, and a fattening system, which merely fattens purchased young animals till the moment of selling. The small ruminant activities for meat and milk production are modelled in a way similar to dairy and beef activities. The milk and meat production is used to determine an appropriate replacement rate and the feed requirements of different animals (Thorne et al., 2009).

FADN data are used to identify the predominant livestock activities across the regions of EU, and to derive related animal shares, production levels and replacement rates. The SEAMLESS survey (Borkowski et al., 2007) and a feed evaluation and animal nutrition system proposed by Jarrige (1989) were used to quantify the technical coefficients of animal activities like yields, total production costs, costs of feed, feed nutrient values and feed requirements (Thorne et al., 2009).

A number of constraints were used to model the on-farm availability of resources, the feed production and the animal's diet. Constraints relating feed availability to feed requirements are used to 
secure that the total requirements of energy, protein and fibre are met by the produced (on-farm) and purchased quantities of feed and concentrates. Another constraint (maximum amount of concentrates) is used to set an upper bound to the share of concentrates in the animal's diet to prevent animal diseases related to high amounts of concentrate. The available amount of roughage constraint restricts the grazing period to a region-specific maxjmum. Finally, the milk quota constraint restricts the produced quantity of milk to the available milk quota. Any milk production exceeding the milk quota is penalized. This constraint is the main limiting factor for a dairy farm and for that reason it is mentioned here as a resource constraint.

\subsubsection{Policies and regulations}

FSSIM is able to simulate a broad range of agricultural and environmental policy instruments, some of which have been already implemented in practice while others might be of interest to policy makers in the future. These policies are modelled as additional constraints and variables in a generic way to account easily for various products or region-specific policy implementation. The policy instruments which are currently modelled in FSSIM can be classjfied in a number of groups.

The first group of policies modelled in FSSIM includes the EU compensation payments which are taken into account as part of revenues in the objective function of the model. Existing compensation payments related to rain-fed and irrigated land, historical yield but also the degree of the payments that is linked to production (coupling) are taken into account in order to calculate the total amount of received payments according to the existing regime. Two farm support policies are already programmed in FSSIM, the farm support policy under the Agenda 2000 (CEC, 1999a,b) and the reform of the Common Agricultural Policy of 2003 (CAP reform of 2003) (CEC, 2003; OECD, 2004). The first CAP reform of 1992 (CEC, 1991) and the market liberalization led to a reduction of product prices. Therefore, a regime of direct payments was developed to compensate farm income within the general context of the Agenda 2000 . These direct payments were given to the highly affected arable and livestock sectors of the EU and they were linked either to production or to the area of different crops. The direct payments are financed by the EU and administered by the ministry or department of agriculture of each member state. Modelling the regional specific implementation of the Agenda 2000 requires two pieces of information: the way the payment was given (i.e. per activity level, per unit of main output) and the amount of the payment (basic premium) per hectare, slaughtered animal or tonne of product. The CAP reform of 2003 replaces the Agenda 2000 regime and involves mainly the partial (or total for some crops) decoulpling of subsidies from production. To calculate subsidies under the CAP reform of 2003 in FSSIM, the subsidies received under the Agenda 2000 were (partially or totally) detached from production. To achieve this, the new coupling degree of each product was used. The decoupled part of the payment is based on the historical reference land and the total amount of subsidies received over the years 2000-2002. The coupled and the decoupled payment of each activity were used to calculate the total received subsidies per hectare of activity under the CAP reform of 2003.

The second group of policy instruments that has been modelled in FSSIM relates to quota based policies which are currently used in many EU countries to regulate the price and supply of certain products like milk and sugar beet. This kind of regulation was also used under Agenda 2000. In FSSIM quota based policies are taken into account with additional constraints. The part of production that exceeds the pre-determined quotas gets a lower price according to the specificities of the regulation. The same structure of the constraint set is used for all products that are currently under a quota regulation (or might be in the future).
Another policy that has been included in FSSIM is the obligatory set-aside policy which was introduced by the EU in 1988 (i) to reduce the large and costly cereal surpluses produced under the guaranteed price system of the CAP reform of 1992 and (ii) to provide environmental benefits following considerable damage to agro-ecosystems and nature as a result of the intensification of agriculture. Although the implementation of the set-aside policy differs across the EU, in general, the measure entails the obligation to leave a proportion of the farm land uncultivated or assigned to non-food purposes for a certain period in exchange for subsidy payments. The obligatory set-aside policy is taken into account in FSSIM by setting a lower bound to the area which is left as setaside and by adding an extra source of revenues in the objective function for each hectare of set-aside. If the area of set-aside is less than $10 \%$ of the area of Cereals, Oil seed and Protein (COP) crops a subsidy cut is assumed.

The last group of policies modelled in FSSIM is related to the environmental conditions and cross-compliance regulations which aim at sustaining various agro-environmental conditions that must be respected to avoid reduced farm support payment under the CAP reform of 2003. Cross-compliance regulations must be in line with a number of well-defined standards determined at EU level and cover environmental, food safety, crop protection, animal health and animal welfare issues. Cross-compliance regulations are taken into account mainly by additional constraints while in some cases binary variables are needed transforming the model into a Mixed lnteger Non-Linear Programming (MINLP) model.

In addition to the above described policy instruments, a number of environmental indicators (e.g. total nitrogen use, water use, pesticide use), indicators related to biodiversity and multi-functionality (e.g. number of crop species on the farm), and socio-economic indicators (e.g. labour use per hour) are assessed. Those indicators can be easily used to evaluate future environmental policies.

\subsection{Calibration and forecasting}

A Positive Mathematical Programming (PMP) based approach is used to calibrate the model and guarantee exact reproduction of the observed (base year) situation without using additional calibration constraints which are difficult to justify in a way consistent with existing economic theory (Heckelei, 2003). PMP is a generic and fully automated procedure which means that it can be easily adapted and used for different regions and farm types without additional site specific information.

In PMP calibrated models, the observed activity levels of farm types are used to calculate unobserved non-linear costs which are omitted from the linear cost function of LP models because of data limitations and simplification purposes. Non-linear costs are related to issues like managerial capacity, fixed costs (e.g. machinery, buildings) and risk. PMP uses a two step approach. In the first step, a number of calibration constraints are added to the model, to ensure that the observed activity levels of the base year are reproduced. In the second step, the calibration constraints are taken out and their shadow prices are used to specify and include the nonlinear costs in the objective function. Since the first introduction of PMP to bio-economic modelling by Howitt (1995) a number of PMP variants have been developed based on different assumptions resulting in different model forecasts (Heckelei and Wolff, 2003; Röhm and Dabbert, 2003; Kanellopoulos et al., 2010). The appropriateness of PMP variants is case specific and depends on the available data and policy question. In FSSIM a number of PMP variants are programmed providing users with various options.

A different calibration procedure is used for the model presented in (2) where the risk aversion coeficient is the only unknown parameter. The risk aversion parameter is estimated in an iterative process that involves multiple model runs. In each model 
run a different value of the risk aversion coefficient is used; the value of the risk aversion coefficient that gives the best fit in terms of crop allocation is selected for simulations. In this case, exact calibration is not guaranteed.

After the model has been calibiated it can be used for forecasting. Inflation of input and output prices is considered, while exogenous to the model information on yield and price trends are used to account for possible technological innovations and price-supply fluctuations.

To facilitate the analysis of policy scenarios, FSSIM is set-up in such a way that policy makers and model users can easily access and adapt the constraint set and the parameters of the model. New policy scenarios can be incorporated into the model by: (i) varying the available farm resources, (ii) changing the input and output coefficients for activities, (iii) abolishing base year policies, and (iv) including new policies, constraints and parameters. A set of general policies has been pre-programmed and is ready to use after having provided the required data.

Fig. 2 shows a simple presentation of the model set-up for a simulation of an arable farm in year 2003, where gross margin is maximized (risk aversion is not taken into account) subject to a number of resource and policy constraints. This presentation reveals the general structure of the model and summarizes the required information that is stored in an integrated database developed within SEAMLESS (Janssen et al., 2009a). Switching on and off different components of the model allows different simulation of the same or a different farm type (e.g. the livestock component is switched on in the case where a livestock farm type is simulated).

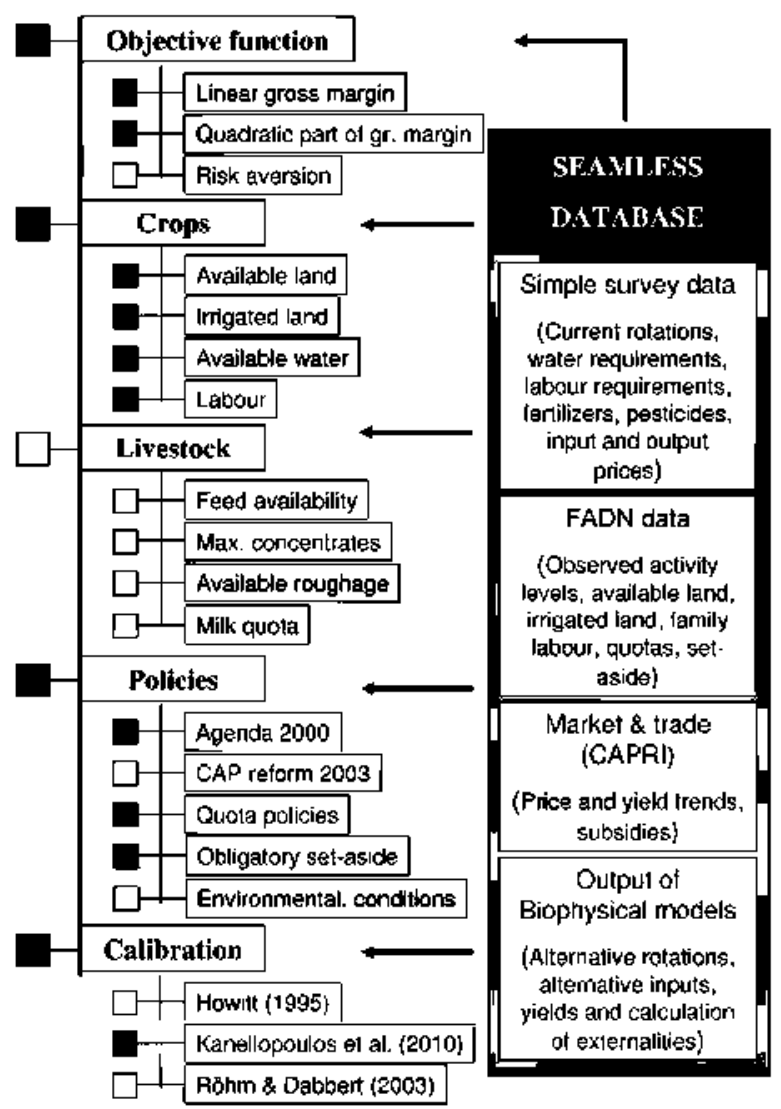

Fig. 2. Set-up of FSSIM for simulating an arable farm type under Agenda 2000 . Switching on (D) and off ( $\square$ ) components and constraints results in different simulations of a different farm type. Summary of the required information stored in the SEAMLESS database.

\section{Set-up of the calculations}

Here, we present the application of FSSIM to arable and dairy farm types in Flevoland (The Netherlands) and Midi-Pyrenees (France). The bio-physical (climate and soil types) and socio-economic (different size, intensity and specialization of arable and livestock farms) conditions of these two regions differ substantially. We have chosen these regions to illustrate the applicability of the model under different bio-physical and socio-economic conditions and demonstrate the generic features of the model enabling the simulation of other farm types within the EU. For this exercise, we did not use a bio-physical model to estimate externalities because of data limitations and simplification purposes. Instead, we used total nitrogen input and total irrigation water input as environmental indicators. The model specification with a non-linear total gross margin function, described in (1), was selected for this exercise because exact calibration is guaranteed. This model specification is used for higher level analysis where data is limited and calibration only on the risk aversion parameter is not adequate to reproduce what is observed in reality. FSSIM was calibrated for the base year (2003) with the PMP variant proposed by Kanellopoulos et al. (2010), using activity specific supply elasticities from the literature (Jansson, 2007). For this exercise we used exogenous base year prices and consequently we did not use the full procedure described in Fig. 1.

We use the four digits codes of the SEAMLESS farm typology to distinguish between the different farm types. The first digit of the farm type code refers to the farm size: (3) Large farms, i.e. size $>\mathbf{4 0}$ European Size Units (ESU), (2) Medium farms (16 ESU $\leqslant$ size $\leqslant$ $40 \mathrm{ESU}$ ), (1) small farms (size $<16 \mathrm{ESU}$ ). The second digit refers to farm intensity: (3) High intensity (output $>3000 € /$ ha), (2) Medium intensity ( $500 \mathrm{e} / \mathrm{ha} \leqslant$ output $\leqslant 3000 \mathrm{e} / \mathrm{ha}$ ), (1) Low intensity (output $<500 \mathrm{e} / \mathrm{ha}$ ). The two last digits refer to farm specialization: (08) dairy cattle/others, (07) dairy cattle/land independent, (06) dairy cattle/temporary grass, (05) dairy cattle/permanent grassland, (04) arable/other, (03) arable specialized crops, (02) arable/fallow, and (01) arable/cereal. The set of constraints, used for the base year (2003) to simulate arable farm types consists of the resource constraints (available land, available irrigated land and labour) and policies (sugar beet quota regime and the obligatory set-aside). For dairy farms the constraints relate to the feed availability, the maximum amount of concentrates in animals' diet, and the grazing period were added. The data requirements for the base year simulations include the available farm resources (i.e. available farm land characterized by soil and climatic conditions, available irrigated land and available family labour) the inputs and outputs of current activities, the observed cropping patterns, the herd composition (Tables 1 and 2 ), the economic data (i.e. variable costs of inputs, output prices and wages) and the policy data (i.e. compensation payments under Agenda 2000, quotas for sugar beet and milk production).

The calibrated model is used to predict changes in total gross margin, agricultural supply and environmental indicators as a consequence of the implementation of the 2003 CAP reform in a context of market liberalization. The time horizon of the simulation is the year 2013 and takes into account (i) new exogenous prices generated by the CAPRI agricultural sector model (Britz et al., 2007) under the market liberalization scenario, (ii) abolishment of the existing quota for sugar beet and milk, (iii) abolishment of the obligatory set-aside policy, and (iv) new subsidjes calculated under the CAP reform of 2003.

The data used for policy scenarios are yields and price trends for year 2013 as calculated by CAPRl (Britz et al., 2007) in a market liberalization scenario. The market liberalization scenario in CAPR] assumes abolishing the export tariffs. It should be noted that this market liberalization scenario within CAPRJ does not include abolishment of quota or of the obligatory set-aside policy. Input and 
Table 1

Famm specific data of farm types in Flevoland in 2003, and, observed crop areas and animal numbers that are included in the current activities. Source: FADN.

\begin{tabular}{|c|c|c|c|c|c|c|c|c|c|c|c|}
\hline & & \multicolumn{5}{|c|}{ Arable farms } & \multicolumn{5}{|c|}{ Dairy farms } \\
\hline & & FT 2303 & FT 3203 & FT 3303 & FT 3304 & Average farm & FT 3205 & FT 3305 & FT 3307 & FT 3308 & Average farm \\
\hline \multicolumn{12}{|l|}{ Fam specific data } \\
\hline $\begin{array}{l}\text { Total available land } \\
\text { lrrigated land }\end{array}$ & $\begin{array}{l}\text { (ha) } \\
\text { (ha) }\end{array}$ & 17.9 & 66.3 & 68.7 & 33.9 & 56.4 & 49.7 & 44.6 & 33.1 & 48.9 & 44.6 \\
\hline Fanily labour & (h) & 3156 & 2997 & 5403 & 7641 & 4754 & 3325 & 4293 & 4440 & 3933 & 4196 \\
\hline Milk quota & (tons) & & & & & & 437 & 555 & 488 & 571 & 543 \\
\hline Costs of hired labour & $\left(E_{f} / h\right)$ & 7.5 & 7.5 & 7.5 & 7.5 & 7.5 & 7.5 & 7.5 & 7.5 & 7.5 & 7.5 \\
\hline Farms represented & $(\%)$ & 13 & 29 & 44 & 15 & & 8 & 78 & 6 & 8 & \\
\hline \multicolumn{12}{|l|}{ Crop areas } \\
\hline Grass (permanent) & (ha) & & & & & & 45 & 35.9 & 18.8 & 19 & 34.2 \\
\hline Maize (silage & (ha) & 1.5 & 2 & 0.6 & 0.1 & 1 & 3.7 & 7.7 & 9.2 & 16.4 & 8.2 \\
\hline Onions & (ha) & 2.2 & 32 & 9.7 & 23.4 & 8.9 & & & 0.2 & 0.6 & 0.1 \\
\hline Potatoes & (ha) & 4.8 & 17.9 & 24.8 & 3.5 & 17.1 & & 0.2 & 0.4 & 1 & 0.3 \\
\hline Set-aside & (ha) & 1.7 & 1.8 & 1.3 & 0.9 & 1.4 & 0.1 & 0.2 & 3 & 5.4 & 0.8 \\
\hline Sugar beet & (ha) & 3.1 & 11.2 & 9.1 & 1.3 & 7.8 & 0.3 & 0.3 & 0.3 & 1.6 & 0.4 \\
\hline Wheat (soft) & (ha) & 2.7 & 10.4 & 11.5 & 2 & 8.7 & & 0.1 & & 1.7 & 0.2 \\
\hline Other crops (not simulated) & (ha) & 2 & 19.8 & 11.7 & 2.8 & 11.5 & 0.6 & 0.3 & 1.2 & 3.1 & 0.6 \\
\hline \multicolumn{12}{|l|}{ Animais } \\
\hline Bulls & (heads) & & & & & & 3 & 2 & 1 & 2 & 2 \\
\hline Calves & (heads) & & & & & & 24 & 25 & 23 & 31 & 25 \\
\hline Cows & (heads) & & & & & & 58 & 74 & 65 & 76 & 72 \\
\hline Heifers & (heads) & & & & & & 17 & 21 & 19 & 22 & 21 \\
\hline Total & (heads) & & & & & & 102 & 122 & 107 & 131 & 120 \\
\hline
\end{tabular}

Table 2

Farm specific data of farm types in Midi-Pyrenees in 2003, and observed crop areas and animal numbers that are included in the current activities. Source: FADN.

\begin{tabular}{|c|c|c|c|c|c|c|}
\hline & & \multicolumn{4}{|c|}{ Arable farms } & \multirow{2}{*}{$\begin{array}{l}\text { Dairy } \\
\text { farm } \\
\text { FT } \\
\text { 2206 }\end{array}$} \\
\hline & & $\begin{array}{l}\text { FT } \\
3201\end{array}$ & $\begin{array}{l}\text { FT } \\
3202\end{array}$ & $\begin{array}{l}\text { FT } \\
3304\end{array}$ & $\begin{array}{l}\text { Average } \\
\text { farm }\end{array}$ & \\
\hline \multicolumn{7}{|l|}{ Fam specific data } \\
\hline Total available land & (ha) & 141.2 & 123.8 & 173.1 & 148.7 & 41.6 \\
\hline Irrigated land & (ha) & 41.8 & 30.4 & 16.5 & 30.9 & 0.8 \\
\hline Fanily labour & (li) & 2902 & 3260 & 3179 & 3067 & 2152 \\
\hline Milk quota & (tons) & & & & & 171 \\
\hline Cost of hired labour & $(\epsilon / h)$ & 7.5 & 7.5 & 7.5 & 7.5 & 7.5 \\
\hline Farms represented & $(\%)$ & 46 & 20 & 34 & & 100 \\
\hline \multicolumn{7}{|l|}{ Crop areas } \\
\hline Barley & (ha) & 4.1 & 1.6 & 2.4 & 3 & 2 \\
\hline Grass (permanent) & (ha) & & & & & 28.4 \\
\hline Maize (grain) & (ha) & 35.1 & 25.1 & 3.6 & 22.3 & 0.1 \\
\hline Maize (silage) & (ha) & 0.3 & 0.5 & 0.7 & 0.5 & 6.3 \\
\hline Peas & (ha) & 3.7 & 3.6 & 6.4 & 4.6 & 0.3 \\
\hline Rape seed & (ha) & 1.7 & 1 & 1.6 & 1.5 & \\
\hline Set-aside & (ha) & 9.3 & 18.9 & 9.4 & 11.2 & 0.5 \\
\hline Soya & (la) & 3 & 3.6 & 7.8 & 4.8 & \\
\hline Sunflower & (ha) & 14.3 & 12.6 & 33.9 & 20.7 & \\
\hline Wheat (durum) & (ha) & 17.3 & 11.4 & 31.6 & 21.1 & \\
\hline Wheat (soft) & (la) & 13.1 & 12.3 & 13.2 & 13 & 0.9 \\
\hline $\begin{array}{l}\text { Other crops (not } \\
\text { simulated) }\end{array}$ & (ha) & 39.3 & 33.2 & 62.4 & 46 & 3.3 \\
\hline Total & (ha) & 141.2 & 123.8 & 173.1 & 148.7 & 41.7 \\
\hline \multicolumn{7}{|l|}{ Animais } \\
\hline Bulls & (heads) & & & & & 1 \\
\hline Calves & (heads) & & & & & 10 \\
\hline Cows & (heads) & & & & & 29 \\
\hline Heifers & (heads) & & & & & 7 \\
\hline Total & (heads) & & & & & 47 \\
\hline
\end{tabular}

output prices are inflated with a constant inflation rate $(1.9 \%)$ in both regions for a period of 10 years. Historical yields, subsidy levels (as those determined in the CAP reform of 2003) and regionspecific decoupling of subsidies from production, were also considered.

Weighted average economic and policy data (prices, yields subsidies, costs and gross margins) for the base year and the 2003 CAP reform for Flevoland and Midi-Pyrenees under the market liberalization scenario are presented in Tables 3 and 4, respectively. The weights are determined from the share of activities observed in each farm type and the share of farm types in the regions. Based on this information, in Flevoland the expected gross margins of silage maize, onjons and soft wheat are projected to increase in 2013 while the expected gross margins of potatoes and sugar beet are projected to decrease substantially. With the CAP reform of 2003 silage maize receives a larger subsidy than other crops. The main reason for this is that most of the silage maize area is at dairy farms which receive a larger subsidy per ha because of the decoupled animal production. Grass products are assumed to be non-tradable products and thus have no price in the model. The expected gross margin decrease of grass is due to increasing costs because of inflation. The large decrease in the price of milk is associated with the market liberalization scenario and it is the reason for the lower expected gross margin per herd unit. In Midi-Pyrenees, the expected gross margins of most crops increase due to higher prices and subsidies. An exception is durum wheat for which the subsidy decreases by almost $67 \%$ resulting in a substantial decrease of expected gross margin. Inflation of the costs is the main reason for the lower expected gross margin of grass while the lower subsidy for set-aside is the main reason for lower expected gross margin of the fallow activity. Similar to Flevoland the average expected gross margin of a herd unit is reduced due to projected lower milk price.

Three model runs were designed to analyse the effects of the different changes during the period 2003-2013 (see Table 5). In the first model run (price-yield change) we included only price and yield changes and inflated input prices for year 2013, assuming market liberalization. In the second model run (set-aside $E$ quota abolishment) we added the abolishment of the obligatory set-aside policy and the quota regimes for both sugar beet and milk. In the third model run (CAP 2003) we added the CAP reform of 2003. In this model run we recalculated subsidies according to the CAP reform of 2003 where decoupling of subsidies from production was decided. Notice that only model run 3 can be considered as a complete policy scenario (all interrelated changes are taken into account simultaneously), the other model runs serve to analyse the effects of the individual changes during period 2003-2013. 
Table 3

Crop product and animal product prices, yields, subsidies, costs and gross margins in 2003 and 2013 in Flevoland. Source: FADN, SEAMLESS survey and CAPRI model.

\begin{tabular}{|c|c|c|c|c|c|c|c|c|c|c|c|}
\hline & \multicolumn{2}{|c|}{$\begin{array}{l}\text { Price } \\
\text { (€्/tonne) }\end{array}$} & \multicolumn{2}{|c|}{$\begin{array}{l}\text { Yield } \\
\text { (tons/ha or tons/head) }\end{array}$} & \multicolumn{2}{|c|}{$\begin{array}{l}\text { Subsidy } \\
\text { (€/ha or } € / \text { head) }\end{array}$} & \multicolumn{2}{|c|}{$\begin{array}{l}\text { Costs } \\
\text { (€flha or } €_{f} \text { head) }\end{array}$} & \multicolumn{2}{|c|}{$\begin{array}{l}\text { Gross margin } \\
\text { (E⿰ha or E/head) }\end{array}$} & \multirow[b]{2}{*}{ Change (\%) } \\
\hline & 2003 & 2013 & 2003 & 2013 & 2003 & 2013 & 2003 & 2013 & 2003 & 2013 & \\
\hline \multicolumn{12}{|l|}{ Crop products } \\
\hline Maize fodder & 30 & 34 & 40.8 & 42.9 & & 448 & 1098 & 1329 & 126 & 567 & 350 \\
\hline Onions & 90 & 109 & 58.4 & 61.4 & & 7 & 2158 & 2611 & 3098 & 4100 & 32 \\
\hline Potatoes & 100 & 74 & 40.9 & 40.5 & & 91 & 2252 & 2725 & 1838 & 340 & -81 \\
\hline Set-aside & & & & & 298 & & 100 & 121 & 198 & -121 & -161 \\
\hline Soft wheat (spring) & 120 & 142 & 7.8 & 8.7 & 298 & 234 & 527 & 638 & 707 & 836 & 18 \\
\hline Soft wheat (winter) & 130 & 154 & 8.6 & 9.6 & 298 & 234 & 524 & 634 & 892 & 1082 & 21 \\
\hline Sugar beet & 75 & 48 & 65.5 & 70.6 & & & 1150 & 1392 & 3763 & 2018 & -46 \\
\hline Grassiand & & & & & & & 267 & 323 & -267 & -323 & -21 \\
\hline Grass dry matter (grazed) & & & 6.0 & 6.6 & & & & & & & \\
\hline Grass dry matter (silage) & & & 4.0 & 4.4 & & & & & & & \\
\hline \multicolumn{12}{|l|}{ Animal products } \\
\hline Bull (meat) & 700 & 695 & 0.0 & 0.0 & & & & & & & \\
\hline Calves (meat) & 108 & 143 & 0.0 & 0.0 & & & & & & & \\
\hline Cows (meat) & 650 & 645 & 0.2 & 0.2 & & & & & & & \\
\hline Cows (milk) & 320 & 275 & 7.5 & 8.9 & & & & & & & \\
\hline Herd unit & & & & & 31 & 59 & $749^{a}$ & 906 & 720 & 633 & -12 \\
\hline
\end{tabular}

average costs before calibration, feed costs are not included.

Table 4

Crop product and animal product prices, yields, subsidies, costs and gross margins in 2003 and 2013 in Midi-Pyrenees. Source: FADN, SEAMLESS survey and CAPRI model.

\begin{tabular}{|c|c|c|c|c|c|c|c|c|c|c|c|}
\hline & \multicolumn{2}{|c|}{$\begin{array}{l}\text { Price } \\
\text { (eftonne) }\end{array}$} & \multicolumn{2}{|c|}{$\begin{array}{l}\text { Yield } \\
\text { (tons/ha or tons/head) }\end{array}$} & \multicolumn{2}{|c|}{$\begin{array}{l}\text { Subsidy } \\
\text { ( } € \text { flua or eflead) }\end{array}$} & \multicolumn{2}{|c|}{$\begin{array}{l}\text { Costs } \\
\text { (efla or efluead) }\end{array}$} & \multicolumn{2}{|c|}{$\begin{array}{l}\text { Gross margin } \\
\text { ( } € \text { ha or } € / \text { head })\end{array}$} & \multirow[b]{2}{*}{ Change (\%) } \\
\hline & 2003 & 2013 & 2003 & 2013 & 2003 & 2013 & 2003 & 2013 & 2003 & 2013 & \\
\hline \multicolumn{12}{|l|}{ Crop products } \\
\hline Barley & 94 & 101 & 5.0 & 5.2 & 304 & 452 & 340 & 411 & 434 & 567 & 23 \\
\hline Maize (grain) & 120 & 152 & 11.0 & 10.5 & 304 & 431 & 859 & 1039 & 765 & 993 & 23 \\
\hline Maize (silage) & 120 & 132 & 15.4 & 17.3 & & 423 & 860 & 1041 & 988 & 1657 & 40 \\
\hline Peas & 133 & 150 & 3.5 & 3.6 & 304 & 448 & 385 & 466 & 385 & 526 & 27 \\
\hline Rape seed & 204 & 318 & 2.2 & 2.2 & 304 & 443 & 582 & 704 & 171 & 451 & 62 \\
\hline Set-aside & & & & & 304 & 156 & & & 304 & 156 & -95 \\
\hline Soya & 196 & 318 & 2.3 & 3.1 & 304 & 450 & 331 & 401 & 424 & 1027 & 59 \\
\hline Sunflower & 213 & 323 & 2.4 & 2.4 & 304 & 451 & 294 & 356 & 521 & 871 & 40 \\
\hline Wheat (durum) & 135 & 148 & 5.0 & 5.8 & 592 & 198 & 421 & 509 & 846 & 546 & -55 \\
\hline Wheat (soft) & 116 & 137 & 6.5 & 7.0 & 304 & 444 & 430 & 520 & 628 & 879 & 29 \\
\hline Grassiand & & & & & & & 72 & 87 & -72 & -87 & -21 \\
\hline Glass dry matter (grazed) & & & 2.3 & 2.5 & & & & & & & \\
\hline Grass dry matter (hay) & & & 3.1 & 3.4 & & & & & & & \\
\hline Grass dry matter (silage) & & & 4.6 & 5.0 & & & & & & & \\
\hline \multicolumn{12}{|l|}{ Animal products } \\
\hline Bull (meat) & 1200 & 1191 & 0.0 & 0.0 & & & & & & & \\
\hline Calves (meat) & 110 & 146 & 0.0 & 0.0 & & & & & & & \\
\hline Cows (meat) & 600 & 595 & 0.2 & 0.2 & & & & & & & \\
\hline Cows (milk) & 320 & 258 & 6.0 & 7.3 & & & & & & & \\
\hline Herd unit & & & & & 30 & 31 & $405^{\mathrm{a}}$ & 490 & 1023 & 800 & -22 \\
\hline
\end{tabular}

average costs before calibration, feed costs are not included.

\section{Results}

In this section weighted average results of different farm types in the two regions are presented; the weights are determined from the relative share (based on number of farms represented) of the farm types in the region, i.e. first, the average farm of each farm type is simulated and then the results were used to calculate weighted average values of arable and dairy farms in each region. The regional average simulated crop levels, the regional average economic results and the calculation of the regional average nitrogen use of arable farms in Flevoland are presented in Fig. 3. Because of the PMP calibration, the simulated crop levels for the base year are exactly the same as the actual levels observed in FADN (Table 1). In the price-yield change model run, the gross margin increase of maize silage, onions and wheat causes a substantial increase in the areas of these crops in arable farming. The gross margin decrease of potatoes and sugar beet causes a decrease in the area of these crops. The decrease of the area of sugar beet is also because of the yield trend ( $8 \%$ increase). Less area of sugar beet are needed to produce the same quota. The average total gross margin of arable farms decreases with more than $28 \%$. The shift of crop production from spring soft wheat to winter soft wheat is the main reason for the increase of the total nitrogen use per ha in all farm types of Flevoland.

In the set-aside $\&$ quota abolishment model run for arable farms, the abolishment of the sugar beet quota system and the obligatory set-aside policy, are the reasons for the increase of the area of sugar beet and the decrease of the area of set-aside (compared to the simulated levels of these activities in the price-yield change model run). Putting the set-aside area in production causes an increase of the average total gross margin of arable farms. The total nitrogen use increased in all farm types because of the decrease of the area 
Table 5

Definition of the base year and the model runs (price-yield change, set-aside \& quota abolishment and CAP 2003).

\begin{tabular}{|c|c|c|c|c|}
\hline & $\begin{array}{l}\text { Exogenous } \\
\text { assumptions }\end{array}$ & Price and yield & $\begin{array}{l}\text { Set-aside and quota } \\
\text { policies }\end{array}$ & $\begin{array}{l}\text { EU compensation } \\
\text { payment }\end{array}$ \\
\hline Base year (2003) & & 2003 price and yield & $\begin{array}{l}\text { With obligatory set-aside } \\
\text { and quota }\end{array}$ & $\begin{array}{l}\text { Agenda } 2000 \text { (direct } \\
\text { payment) }\end{array}$ \\
\hline $\begin{array}{l}\text { Price-yield change } \\
\text { (2013) }\end{array}$ & $\begin{array}{l}\text { Inflation rate of } \\
1.9 \% \text { per year }\end{array}$ & $\begin{array}{l}\text { Projection in prices and yields from } 2003 \text { to } 2013 \\
\text { accounting for market liberalization }\end{array}$ & $\begin{array}{l}\text { With obligatory set-aside } \\
\text { and quota }\end{array}$ & $\begin{array}{l}\text { Agenda } 2000 \text { (direct } \\
\text { payment) }\end{array}$ \\
\hline $\begin{array}{l}\text { Set-aside \& quota } \\
\text { abolishment (2013) }\end{array}$ & $\begin{array}{l}\text { Inflation rate of } \\
1.9 \% \text { per year }\end{array}$ & $\begin{array}{l}\text { Projection in prices and yields from } 2003 \text { to } 2013 \\
\text { accounting for market liberalization }\end{array}$ & $\begin{array}{l}\text { Abolishing set-aside } \\
\text { obligation and quota }\end{array}$ & $\begin{array}{l}\text { Agenda } 2000 \text { (direct } \\
\text { payment) }\end{array}$ \\
\hline CAP 2003 (2013) & $\begin{array}{l}\text { Inflation rate of } \\
1.9 \% \text { per year }\end{array}$ & $\begin{array}{l}\text { Projection in prices and yields from } 2003 \text { to } 2013 \\
\text { accounting for market liberalization }\end{array}$ & Abolishing set-aside obligation and quota & $\begin{array}{l}2003 \text { CAP reform } \\
\text { (decoupled payment) }\end{array}$ \\
\hline
\end{tabular}
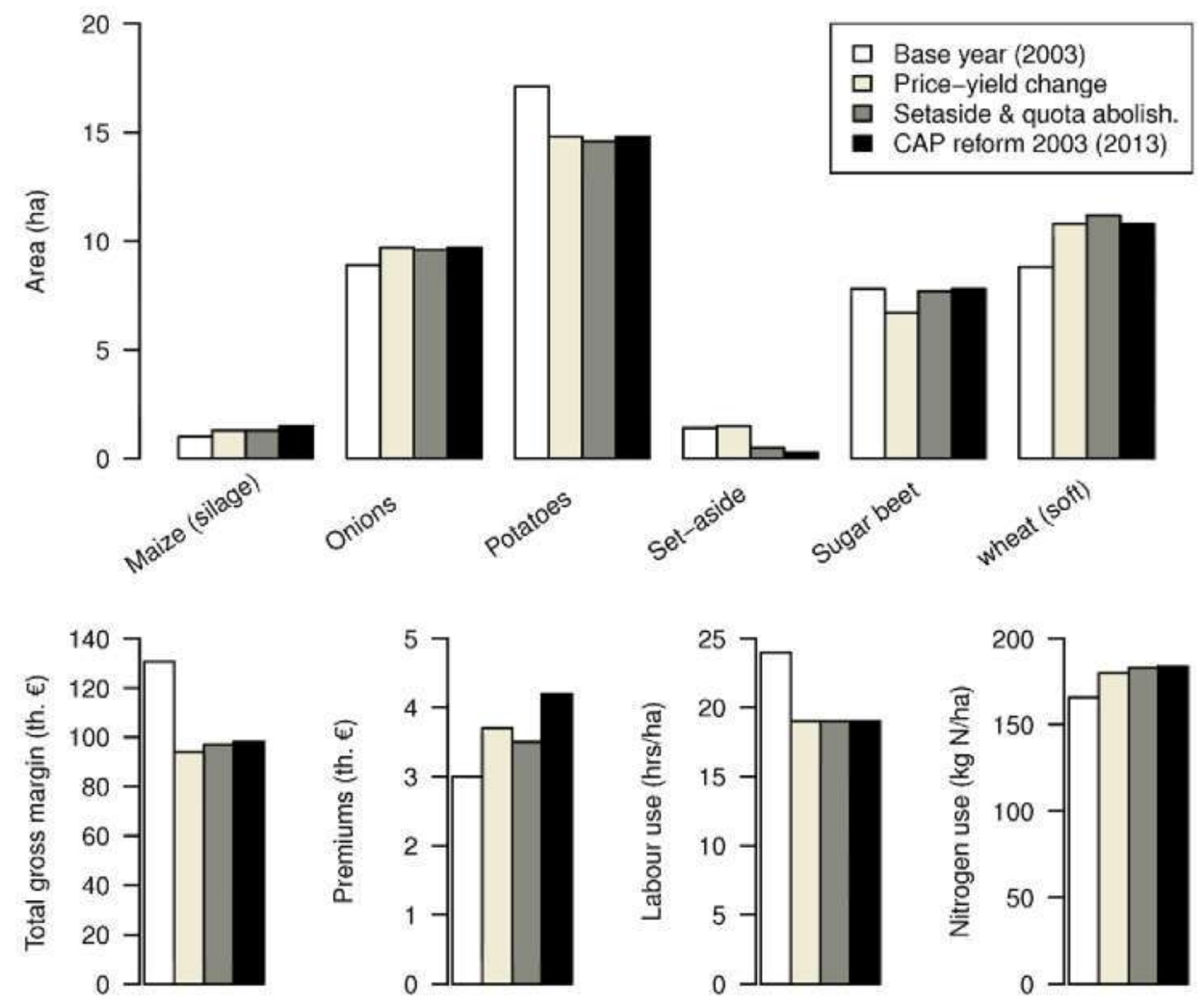

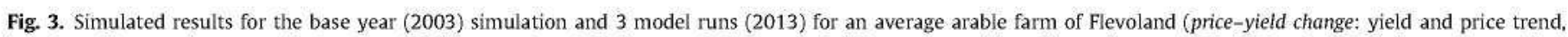

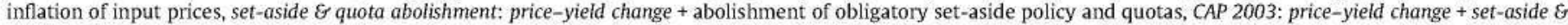
quota abolishment + CAP reform of 2003).

of set-aside and the increase of the area of the more nitrogen demanding winter soft wheat.

In the CAP 2003 model run, overall effects on crop allocation are very modest compared to the set-aside \& quota abolishment, model run and the associated effect on the total gross margin negligible.

The regional average weighted results of the simulated dairy farms in Flevoland are presented in Fig. 4. The produced feed reported in Fig. 4 corresponds to on-farm feed production that is used on-farm excluding sold quantities of on-farm produced feed. Similar to the base year simulation of the arable farms and because of the PMP calibration, the observed activity levels of crops and animals of the dairy farms are reproduced exactly. In the priceyield change model run the total number of animals of the herd decreases because of the increased milk production per cow and the given quota. The area of permanent grassland decreases but the on-farm feed production of grass increases because of the assumed yield increase. The amount of silage maize sold increases because of the price increase. The share of grass in the diet increases and as a result the amount of concentrates also increases to fulfil the animals energy requirements while respecting their intake capacity. The gross production decreases mainly because of the decrease in the price of milk. The total costs increase because of the higher input and feed prices and the increased feed requirements. As a result, the total gross margin decreases by almost $35 \%$. The total nitrogen use remains almost the same in all dairy farm types of Flevoland.

In the set-aside \& quota abolishment model run where the milk quota is abolished, the total number of animals increases by $1.7 \%$ compared with the base year simulation and by almost $13 \%$ from the price-yield change model run. The increased feed requirements are covered by increasing purchases of concentrates and silage maize. The total gross margin increases by almost $16 \%$ from the total gross margin of the price-yield change model run while the total nitrogen use remained almost the same.

In the CAP 2003 model run, the CAP reform of 2003 and mainly the large increase of the subsidy for maize silage causes a shift of 

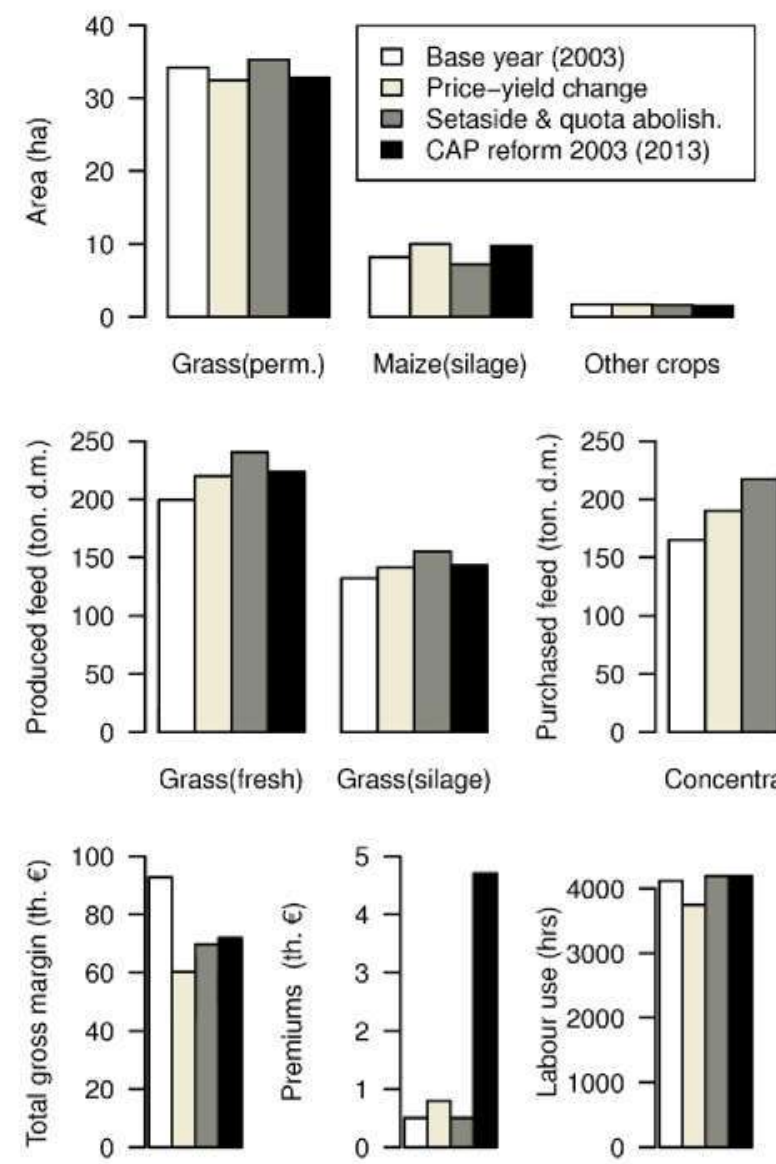
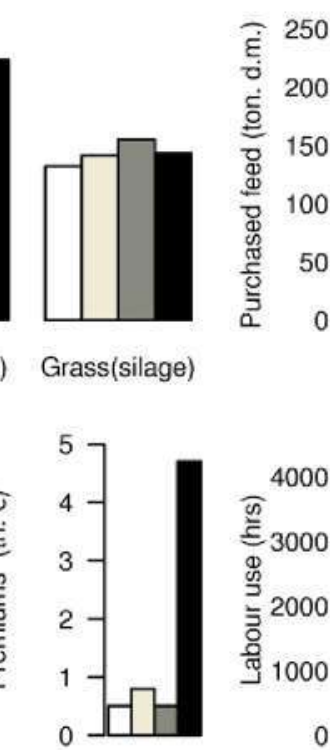
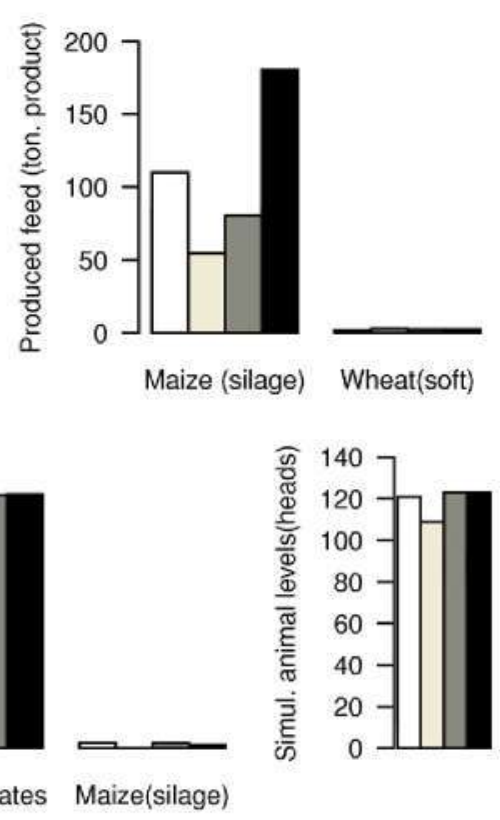

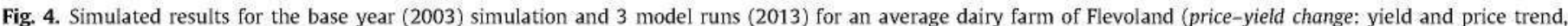

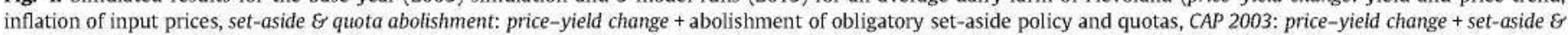
quota abolishment + CAP reform of 2003).

production from grass to maize silage. The received premiums under the CAP reform of 2003 for dairy farms increase substantially, causing a modest increase of the farm's total gross margin.

The regional average weighted results from the application of FSSIM to the arable farms of Midi-Pyrenees are presented in Fig. 5. In the price-yield change model run, the predicted changes for 2013 of gross margins resulted in an increase of the areas of soya, rape seed and silage maize and a decrease in the areas of barley and peas. The average total gross margin of arable farms increases by $24 \%$. The main reason for this is the large price increase of oil seed crops.

In the set-aside \& quota abolishment model run the set-aside obligation of arable farms is abolished putting almost $70 \%$ of the set-aside area of the price-yield change model run into production. The set-aside land is allocated to all other crops. The intensification of production caused a large increase of the average total gross margin of arable farms but also a substantial increase of the total nitrogen use compared to the price-yield change model run.

The recalculation of subsidies according to the CAP reform of 2003 caused a large increase of the received subsidies for most crops. Exceptions are the subsidies for durum wheat and set-aside land, which decrease by 67 and $49 \%$, respectively, causing a decrease of the average area of these activities. The total gross margin decreased by $1.5 \%$ compared with the set-aside \& quota abolishment, model run and increased by $24 \%$ and $54 \%$ compared with the price-yield change model run and base year, respectively.

Regional average weighted results from the application of FSSIM to the dairy farms of Midi-Pyrenees are presented in Fig. 6. Similar to the dairy farm of Flevoland, the produced feed re- ported in Fig. 6 corresponds to on-farm feed production that is used on-farm, excluding sold quantities of on-farm produced feed. In the price-yield change model run, the substantial increase of feeding costs and input prices; and the price decrease of milk caused a small decrease in the average herd size in Midi-Pyrenees. The area of permanent and temporary grasslands decreases and it is substituted mainly by silage maize and barley. On-farm produced grass and the more expensive purchased concentrates in this model run are substituted by cereals and silage maize to cover the animal's feed requirements. The gross margin decreases by $6 \%$.

Abolishment of the milk quota policy in the set-aside \& quota abolishment model run increases the average herd size back to the level of the base year. Labour availability becomes a binding constraint and therefore the number of animals does not exceed the number of animals observed in the base year. The grassland area increases compared to the price-yield change model run substituting the area with silage maize which is not fed to the animals. In both Flevoland and Midi-Pyrenees it is expected that the yield of milk in 2013 will have increased with $19 \%$ and $22 \%$, respectively, causing an increase in the animals' feed requirements. To cover the additional requirements for feed, more grass silage and purchased concentrates are needed. Abolishment of the milk quota caused an increase to the farm's total gross margin.

The effects of the CAP reform 2003 (tested in the CAP 2003 model run) relative to the results of the set-aside \& quota abolishment model run are marginal. The large increase of subsidies on maize silage in the CAP 2003 model run caused an increase of the area of silage maize and a decrease of the area of cereals (mainly barley) and grassland compared to the set-aside E quota abolishment model 

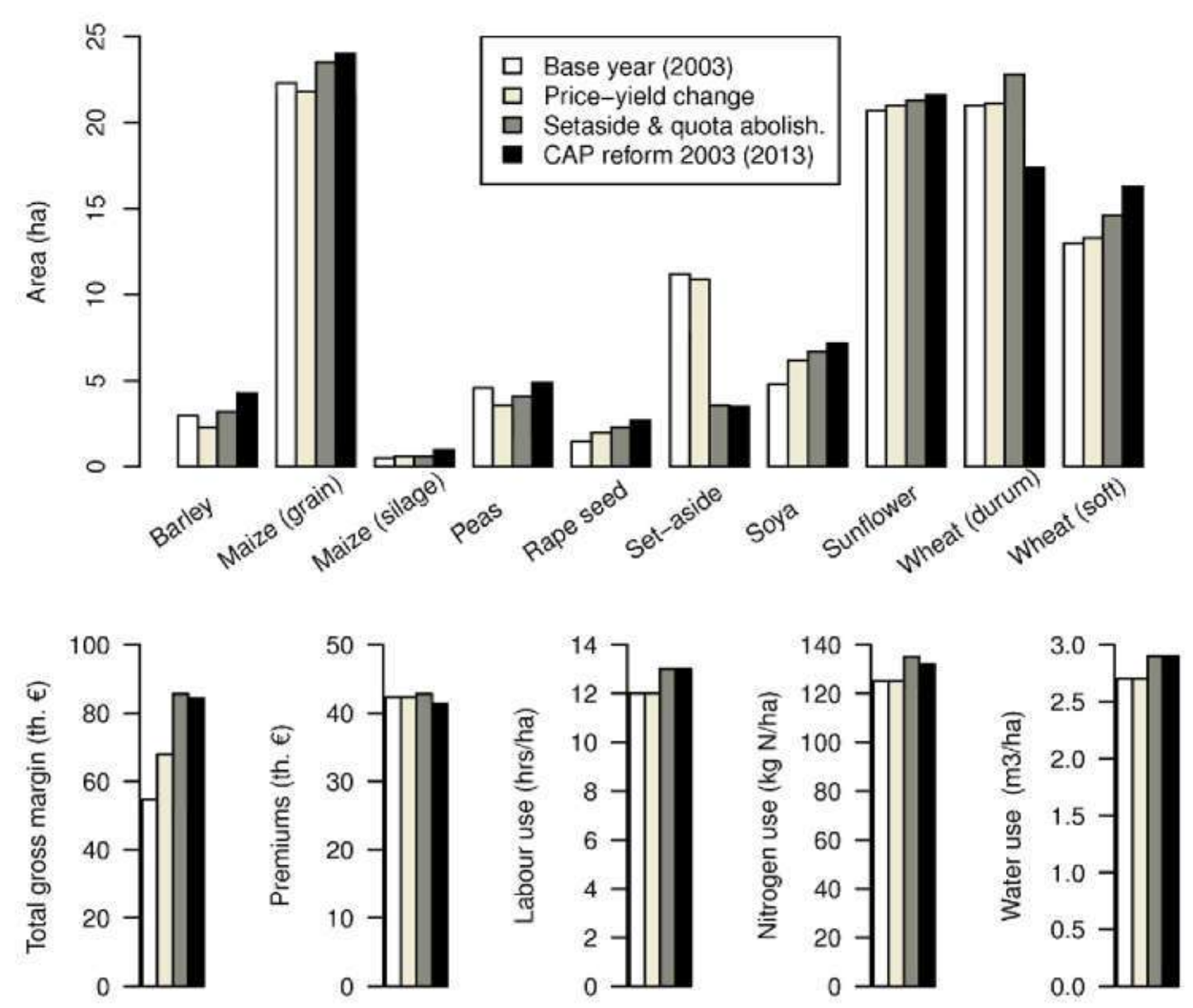

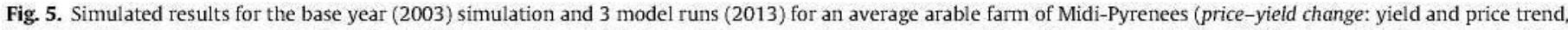

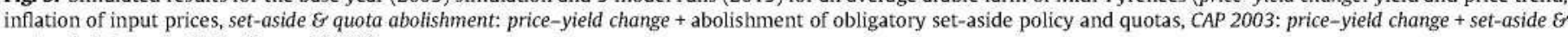
quota abolishment + CAP reform of 2003).

run. The decreased amount of barley fed to the animals is compensated by purchased concentrates. A small amount of hired labour is needed to cover the additional labour requirements of maize. Water and nitrogen use remain almost the same in all model runs.

\section{Discussion and conclusion}

In this article, a bio-economic farm model has been presented that is modular and can be used to simulate the responses of farms to agricultural and environmental policies in a broad range of contexts that may occur in the EU27. This was achieved by: (i) separating model and data and creating a consistent European database for farm types, their locations and production activities, (ii) designing the model in a modular way, that allows switching on and off modules, constraints or calibration methods, (iii) providing adequate documentation, and (iv) ensuring public availability. The arable and dairy farms of two regions that differ substantially from a bio-physical and socio-economic point of view were simulated successfully, using information mainly available in a large EU-wide database (i.e. FADN) and a relatively simple survey conducted within SEAMLESS for a sample of regions representative for the EU27. The PMP based calibration of FSSIM does not require additional region-specific knowledge and detailed information on specific constraints to guarantee exact calibration. Nevertheless, availability of this kind of information could be easily exploited and used to improve the forecasting performance of the model.

The market of land, possibilities for off-farm labour and structural changes are usually issues exogenous to the system definition of bio-economic farm models (Janssen and Van Ittersum, 2007). This is how these issues were also treated in the model presented in this article, but we have indicated in Section 2 and 3 how they can be partially dealt with, using FSSIM and a scenario approach. To simulate farm structural change and land markets more comprehensively FSSIM needs to be combined with other models that account for market and sector level changes, as has been attempted in the SEAMLESS modelling framework (Pérez Domínguez et al., 2009; Zimmermann et al., 2009).

In the present article we illustrate the standalone value of FSSIM using applications in two regions and different farming systems. The applications raise a number of discussion points because of a number of decisions concerning the set-up of the model. First, the presented applications were based on data available in the Farm Accountancy Data Network and a simple survey on agricultural management. This led to a restricted set of environmental indicators, i.e. the total amount of water used for irrigation, and the total amount of nitrogen used. This hinders a comprehensive overview of the environmental implications of the market liberalization under the CAP reform of 2003. The use of a bio-physical model to calculate technical coefficients that can easily be exploited in FSSIM would increase the number of environmental indicators and thus improve the overall assessment of the environmental impact of the tested scenario. However, this requires detailed agro-management data (timing and precise quantities of inputs per crop) that are not available in pan-European data-sets.

Second, we used an average farm type in our simulations to ensure that all important crop products that are produced by farms of a specific farm type will be part of the simulated production plan. This is very important for the type of analysis that requires full representation of agricultural production to determine equilibrium between supply and demand, such as in SEAMLESS (Van Ittersum et al., 2008). However, simulating the average farm has also important drawbacks. An average farm and an average farmer do not actually exist and consequently, an average activity pattern also 

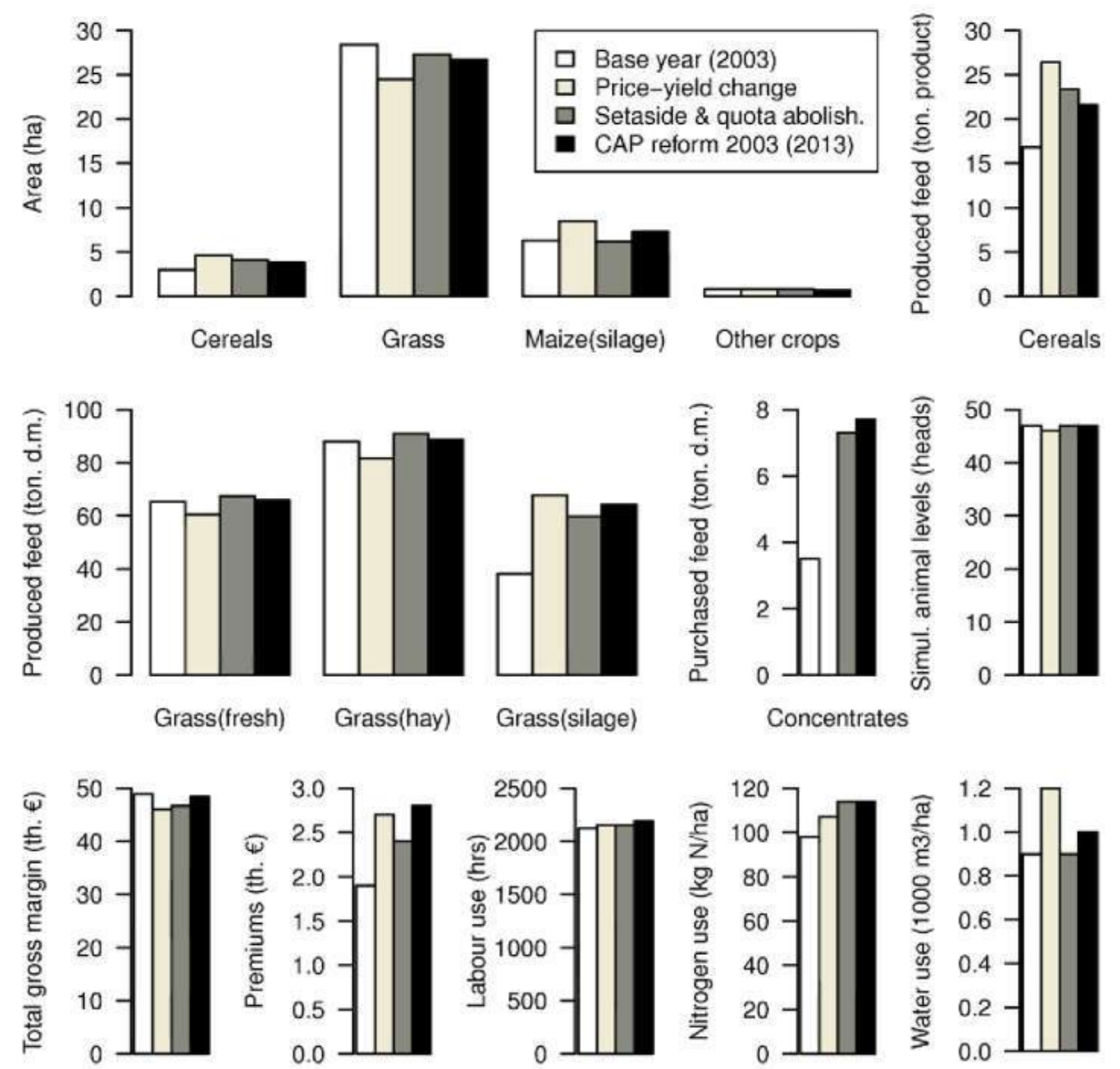

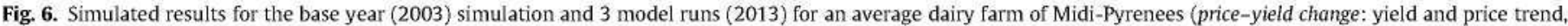

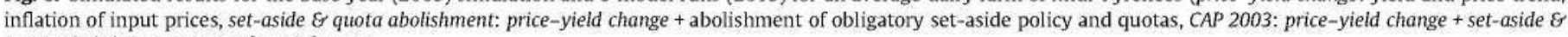
quota abolishment + CAP reform of 2003).

does not exist. The activity pattern of the average farm is much more diversified than that of individual farms. Reproducing such a cropping pattern using an LP model would require a large number of binding constraints. It is possible that such constraints do not even exist in reality and consequently they are difficult to define (e.g. rotational constraints of an "average" production plan). In such cases, calibration of the LP model is necessary for reproducing the observed activity levels and often calibration will dominate the simulations. It is possible that the impact of calibration on the results of the model would be reduced substantially if a number of individual farms were simulated instead of a single average farm. However, this would also have increased the computational requirements and individual farm data would have to be available which is usually not the case (individual farm data are usually confidential and not available for research).

Finally, we assume a yield trend (based on forecasts of the sector model (CAPRI) to represent technological innovation. However, the rapid changes in the socio-economic and the bio-physical environment might lead to a broader variety of alternative activities that will become available to farmers in the future with even completely different inputs and outputs. Such alternative activities cannot be ignored and should be taken into account in ex-ante evaluation of agricultural and environmental policies. Offering alternative activities in FSSIM is possible from a technical point of view. The difficulty is to identify a consistent and feasible set of alternative activities for all regions across the EU.

Apart from using our intuition to assess the model's forecasting performance, it is very difficult to evaluate the results in a quanti- tative and more objective way because they refer to future events and they use simulated data to account for price and yield trends. The quality of the results of FSSIM has been previously evaluated and assessed in ex-post experiments that demonstrate the capacity of the model to simulate the future behaviour of the farmer (Kanellopoulos et al., 2010). Even though, the results of such ex-post exercises cannot be generalized they do increase the confidence in the model's predictions.

A well calibrated and tested bio-economic farm model can be used for ex-ante assessment of the impacts of new policies. Different farming systems across EU can be affected in different ways and consequently farmers respond differently when they are confronted with market and policy changes. This was confirmed by the results presented in this article. For example, price and yield changes are the main factor explaining the gross margin decrease of farms in Flevoland. In Midi-Pyrenees, simulated price and yield changes have the opposite effect on the total gross margin of arable farms, and for this region the abolishment of obligatory set-aside has an additional positive effect on the total gross margin of arable farms. In Flevoland farms showed an increase in premiums under the CAP 2003 reform scenario, whereas in Midi-Pyrenees the CAP 2003 scenario did not further increase the already high level of premiums. The variation in farm's behaviour should be taken into account for efficient and effective policy assessment. Bio-economic modelling can be a useful tool for exploring this variation.

FSSIM has been set-up such that it can readily simulate farm types in very different contexts (climate, soils and socio-economic conditions) and for different purposes. The presented examples in 
this paper show a fairly detailed analysis for the farm types of two regions. The reusability of the model was confirmed by the significant number of applications that have been published (Louhichi et al., 2008, 2009; Kanellopoulos et al., 2009; Majewski et al., 2009; Mouratiadou et al., 2010; Traoré et al., 2009). Pérez Domínguez et al. (2009) show how results of the model can be used for linking micro and macro level analysis of market changes. The model is available under an Open Source license (www.seamlessassociation.org) and through its broader use it can be further tested and new modules can be added.

\section{Acknowledgements}

The work presented in this publication was funded by the SEAMLESS Integrated Project, EU 6th Framework Programme for Research Technological Development and Demonstration, Priority 1.1.6.3 Global Change and Ecosystems (European Commission, DG Research, Contract No. 010036-2).

\section{References}

Andersen, E., Elbersen, B., Godeschalk, F., Verhoog, D., 2007. Farm management indicators and farm typologies as a basis for assessment in a changing policy environment. Journal of Environmental Management 82, 352-362.

Berentsen, P.B.M., 2003. Effects of animal productivity on the costs of complying with environmental legislation in Dutch dairy farming. Livestock Production Science $84,183-194$.

Borkowski, N., Hecker, J.-M., Louhichi, K., Blanco Fonseca, M., Janssen, S., Van Ittersum, M.K., Stokstad, G., Zander, P., 2007. Surveying crop management data for bio-economic farm models. In: Hatfield, J., Donatelli, M., Rizzoli, A. (Eds.), Farming Systems Design 2007: An lnternational Symposium on Methodologies for Integrated Analysis of Farm Production Systems, Catania, Sicily. Italy, vol. 1. pp. 33-34.

Britz. W. Pérez, l., Zimmermann. A. Heckelei, T., 2007. Definition of the CAPRl Core Modelling System and Interfaces with other Components of SEAMLESS-JF. SEAMLESS Report No. 26, SEAMLESS Integrated Project, EU 6th Framework Progranme. Contract No. 010036-2, p. 114, «www seamlessassociation.org>.

CEC, 1991. The Development and Future of the Common Agricultural Policy. COM (91) 258 Final.

CEC, 1999a. Agricultural Council: Political Agreement on CAP Reform. DG Agriculture Newsletter, March 11, 1999. Brussels (special edition).

CEC. 1999b. Berlin European Council: Agenda 2000. Conclusions of the Presidency. DG Agriculture Newsletter, April 1999, Brussels.

CEC. 2003. Reform of the Common Agricultural Policy: Medium-term Prospects for Agricultural Markets and Income in the European Union, December, Brussels. <http://www europa.eu.int/comm/agriculture/publi/caprep/prospects2003b/ fulliep.pdf>.

Donaldson, A.B., Flichman, G., Webster, J.P.G., 1995. Integrating agronomic and economic models for policy analysis at the farm level: the impact of CAP reform in two European regions. Agricultural Systems 48, 163-178.

EC. 2005. Impact Assessment Guidelines. European Commission, Brussels. p. 99.

EEC. 1985. Commission Decision of the 7th of June 1985. Establishing a Community Typology for Agricultural Holdings (OJ L 220, 17.8.1985, p. 1).

Elbersen, B., Kempen, M., Van Diepen, K., Hazeu, G., Verhoog. D., Andersen, E., 2006. Protocols for Spatial Allocation of Fam Types. SEAMLESS Report No. 19, SEAMLESS Integrated Project, EU 6th Framework Programme, Contract No. 010036. p. 99, 〈www seamlessassociation.org>

Flichman, G., 1996. L'evaluation micro-economique de la reforme de la PAC par un modele bio-economique: une illustration sur la region de Toulouse. In: Reyniers, F.N., Benoit-Cattin, M. (Eds.), Linking-Agricultural-Models: SeminarProceedings, Montpellier, France. CIRAD-CA, IAM, Montpellier, France, pp. 7175 .

Flichman, G., Jacquet, F., 2003. Couplage des modèles agronomiques et économiques: intérêt pour l'analyse des politiques. Caliers d'écononie et Sociologie Rurales 67, 1-20.

Hazell, P., Norton, R., 1986. Mathematical Programming for Economic Analysis in Agriculture. Macmillan, New York

Hazeu, G., Elbersen, B., Andersen, E., Banth, B., Van Diepen, K., Metzger, M., 2010. A bio-physical typology for a spatially-explicit agri-environmental modeling framework. In: Brouwer, F., Van Ittersum, M.K. (Eds.), Environmental and Agricultural Modelling: Integrated Approaches for Policy Impact Assessment. Springer Academic Publishing. Dordrecht.

Heckelei, T., 2003. Positive Mathematical Programming: Review of the Standard Approach, CAPRI Working Papers 97-03. <http://www.agp.uni-bonn.de/agpof rsich/caprifwrkpap_e.htm.

Heckelei, T., Wolf, H., 2003. Estimation of constrained optimisation models for agricultural supply analysis based on generalized maximum entropy. European Review of Agricultural Economics 30, 27-50.

Howitt. E.R., 1995. A calibration method for agricultural economic production models. Journal of Agricultural Economics 46. 147-159.
Janssen, S., Van Ittersum, M.K., 2007. Assessing farm innovations and responses to policies: a review of bio-economic farm models. Agricultural Systems 94, 622636.

Janssen, S., Andersen, E., Athanasiadis, I., Van lttersum, M., 2009a. A database for integrated assessment of European agricultural systems. Environmental Science \& Policy 12, 573-587.

Janssen, S., Van Ittersum, M.K., Meuter, E., Louhichi, K., Flichman, G., Blanco, M., Zander, P., Borkowski, N., Hecker, M., Stokstad, G., Romstad, E., Kanellopoulos, A., Berentsen, P., Hengsdijk, H., Van Keulen, H. Thorne, P., Thornton, P., Li, H. Rizzoli, A.E., Heckelei, T., 2009b. Integration of All F55IM Components within SEAMLESS-IF and a Standalone Graphical User Interface for FSSIM. SEAMLESS Report No. 38, SEAMLESS Integrated Project, EU 6th Framework Programme, Contract No. 010036-2, «www seamlessassociation,orgs.

Jansson, T., 2007. Econometric Specification of Constrained Optimization Models. PhD dissertation. Bonn University. <http://wwwilr1.uni-bonn.de/agpo/rsrch/ capri/wrkpape.htm> (electronic publication).

Jarrige, R., 1989. Ruminant Nutrition. Recommended Allowances and Feeding Tables, INRA, Paris, France.

Judez, L., Chaya, C., Martinez, S., Gonzalez, A.A., 2001. Effects of the measures envisaged in "Agenda $2000^{\circ}$ on arable crop producers and beef and veal producers: an application of Positive Mathematical Programming to representative farms of a Spanish region. Agricultural Systems 67, 121-138.

Kanellopoulos, A. Hengsdijk, H., Janssen, S., Van Ittersum, M.K., 2009. Ex-ante assessment of the abolishment of the EU set aside policy: results from a bioeconomic farm analysis. In: Proceedings of the Conference on Integrated Assessment of Agriculture and Sustainable Development Setting the Agenda of Science and Policy (AgSAP 2009). Egmond aan Zee, The Netherlands, 10-12 March 2009. Wageningen University and Researcl Centre. Wageningen, pp. 478-479.

Kanellopoulos, A., Berentsen, P.B.M., Heckelei, T., Van lttersum, M.K., Oude lansink, A.G.J.M., 2010. Assessing the forecasting performance of a generic bio-economic farm model calibrated with two different PMP variants. Journal of Agricultural Economics 61, 274-294.

Louhichi, K., Belhouchette, H., Flichman, G., Therond, O., Wery, J., 2008. Impact assessment of the 2003 CAP reform and the nitrate directive on the arable farming system in the Midi-Pyrénées region: bio-economic modelling at field farm and regional levels. In: 109th Seminar, November 20-21, 2008, Viterbo, ltaly.

Louhichi, K., Hengsdijk, H., Janssen, S., Bigot, G., Perret, E., 2009. EU dairy farming in the face of change: an exploration using a bio-economic farm model. In: Proceedings of the Conference on Integrated Assessment of Agriculture and Sustainable Development Setting the Agenda of Science and Policy (AgSAP) Egmond aan Zee, The Netherlands, 10-12 March 2009. Wageningen University and Researcl Centre, Wageningen, pp. 262-263.

Majewski, E., Was, A., Belhouchette, H., Louhichi, K., Mouratiadou, I., 2009. Impact Assessment of policy changes on the arable sector using the FSSIM model: case study of the Zachodniopomorskie NUTS region. In: Proceedings of the Conference on lntegrated Assessment of Agriculture and Sustainable Development Setting the Agenda of Science and Policy (AgSAP). Egmond aan Zee, The Netherlands, 10-12 March 2009. Wageningen University and Research Centre, Wageningen, pp. 484-485.

Mouratiadou, I., Russell, G., Topp, C., Louhichi, K., Moran, D., 2010. Modelling common agricultural policy-water framework directive interactions and costeffectiveness of measures to reduce nitrogen pollution. Water science \& Technology 61, 2689-2697.

OECD. 2004. Analysis of the 2003 CAP Reform. OECD Publication. 53p.

Onate, J.J., Atance, I., Bardaji, I., Llusia, D., 2006. Modelling the effects of alternative CAP policies for the Spanish high-nature value cereal-steppe farming systems. Agricultural Systems 94, 247-260.

Pérez Domínguez, I., Bezlepkina, l., Heckelei, T., Romstad, E., Oude Lansink, A. Kanellopoulos, A., 2009. Capturing market impacts of farm level policies: a statistical extrapolation approach using biophysical characteristics and farm resources. Environmental Science \& Policy 12, 588-600.

Riesgo, L., Gomez-Limon, JA., 2006. Multi-criteria policy scenario analysis for public regulation of irrigated agriculture. Agricultural Systems 91, 1-28.

Röhm, O., Dabbert, S., 2003. Integrating agri-environmental programs into regional production models: an extension of positive mathematical programming American Journal of Agricultural Economics 85, 254-265.

Semaan. J., Flichman. G. Scardigno, A., Steduto. P., 2007. Analysis of nitrate pollution control policies in the irrigated agriculture of Apulia Region (Southern ltaly): a bio-econonic modelling approach. Agricultural Systems $94,357-367$.

Thorne, P... Hengsdijk, H., Janssen, S., Louhichi, K., Van Keulen, H., Thornton, P.K. 2009. Modelling Livestock Component in FSSIM, SEAMLESS Report No. 35, SEAMLESS Integrated Project. EU Gth Framework Programme, Contract No. 010036-2, p. 73. <www. seamlessassociation.org>.

Topp, C.F.E., Mitchell, M., 2003. Forecasting the environmental and socio-economic consequences of changes in the common agricultural policy. Agricultural Systems 76, 227-252.

Traoré, B., Louhichi, K., Rapidel, B., 2009. A bio-econonic model to analyse the performance of the cotton sector in Mali. In: Proceedings of the Conference on Integrated Assessment of Agriculture and Sustainable Development Setting the Agenda of Science and Policy (AgSAP). Egmond aan Zee, The Netherlands, 10-12 March 2009. Wageningen University and Research Centre, Wageningen, pp. 276-277.

Van Ittersum, M.K., Ewert, F., Heckelei, T., Wery, J., Alkan Olsson, J., Andersen, E. Bezlepkina, l., Brouwer, F., Donatelli, M., Flichman, G., Olsson, l., Rizzoli, A.E., 
van der Wal, Wien, J.E., Wolf, J., 2010. Integrated assessment of agricultural systems - a component-based framework for the European Union (SEAMLESS). Agricultural Systems $96,150-165$.

Veysset, P., Bebin, D., Lherm, M., 2005. Adaptation to Agenda 2000 (CAP reform) and optimisation of the farming system of French suckler cattle farms in the Charolais area: a model-based study. Agricultural 5ystems 83. 179-202.
Zander, P., Borkowski, N. Hecker, J.-M., Uthes, 5., Stokstad, G., Rorstad, P.K., Bellocchi, G., 2010. Procedure to Identify and Assess Current Activities, SEAMLE5S Report No. 50. SEAMLE55 Integrated Project. EU 6th Framework Programme, Contract No. 010036-2. <www.seamlessassociation.org>.

Zimmermann. A. Heckelei, T., Pèrez Dominguez, 1., 2009. Modelling farm structural change for integrated ex-ante assessment: review of methods and determinants. Environmental Science \& Policy 12, 601-618. 